\title{
EMPLOYEES' ENGAGEMENT AND CUSTOMERS' LOYALTY FOR UTILITARIAN SERVICES: A MODERATED MEDIATION MODEL
}

\author{
Sajjad Ahmad Afridi ${ }^{1 *}$, Wajid Khan ${ }^{2}$, Asad Javed ${ }^{3}$, Muhammad Waseem ${ }^{4}$, Kaleem Saifullah ${ }^{5}$
}

${ }^{1 * 4}$ Assistant Professor, Department of Management Sciences, Hazara University Mansehra, Pakistan; ${ }^{2}$ Assistant Professor, Department of Management Sciences, University of Baltistan Skardu, Pakistan; ${ }^{3,5}$ Lecturer, Department of Management

Sciences, Hazara University Mansehra, Pakistan.

Emails: ${ }^{1 *}$ mrafridi79@gmail.com, ${ }^{2}$ wajiduomm@gmail.com, ${ }^{3}$ asadjaved@ @u.edu.pk, ${ }^{4}$ mwaseem@ @u.edu.pk,

${ }^{5}$ kaleemkk@hotmail.com

Article History: Received on $20^{\text {th }}$ April 2021, Revised on $12^{\text {th }}$ May 2021, Published on $18^{\text {th }}$ May 2021

\begin{abstract}
Purpose of the study: The present study aimed to determine the impact of employee engagement on customers' loyalty through customers' engagement. Moreover, this study also aimed to examine the moderating role of customers' trust and the mediating role of customers' engagement on the relationship between employees' engagement and customers' loyalty.
\end{abstract}

Methodology: The data were collected from 220 insurance service users through a non-probability sampling technique. Data reliability and validity were confirmed through Cronbach's alpha and confirmatory factor analysis and hypotheses were tested through Andrew F. Hayes model 7.

Main Findings: Results show a significant direct effect of employee engagement on customers' loyalty. Moreover, the findings confirmed the significant role of customers' engagement as a mediator between employee engagement and customers' loyalty. Results also confirmed customers' trust moderating effect between employee engagement and customers' engagement. Furthermore, the result confirmed the mediation of trust-based-customers engagement between the link of employee engagement and customers' loyalty.

Applications of this study: This study would have some positive repercussions for utilitarian services such as insurance services providers. For instance, this study's findings revealed the process through which companies can make customers more loyal. Insurance companies through their employees' engagement and customer engagement can make a dyade that can better explain customers' loyalty.

Novelty/Originality of this study: This study explored the underlying mechanism that links employee engagement to customers' loyalty. Moreover, this study introduces a new term "trust-based engagement" as an important attribute in enhancing customers' loyalty in general and particularly for insurance companies.

Keywords: Employee Engagement, Customers' Engagement, Customers' Loyalty, S-D Logic, Service-Profit Chain TrustBased Customers Engagement.

\section{INTRODUCTION}

Customer's foremost or in some cases the only connection with insurance service providers is through front-line employees. The positive attitude of the frontline employee during interaction with the service receiver is considered as a key for a satisfying customer experience that eventually leads to customers' loyalty to the service provider (Cain, Tanford, \& Shulga, 2018). Employee engagement (EE) is considered as one of the basic primacies for service organizations (Young, Glerum, Wang, \& Joseph, 2018) during the interaction between frontline employees and customers. EE is a workplace approach leading to the correct circumstances for all staff to relinquish their best, committed to their organization's goals and values with a strengthened sense of their well-being. EE is conceptually defined as "a positive, fulfilling, work-related state of mind that is characterized by vigor, dedication, and absorption (Schaufeli, Salanova, González-Romá, \& Bakker, 2002, p. 465)". Since Insurance companies provide services, they require a significant level of interactions between service employee and customer, henceforth, employee engagement is crucial for a successful service outcome (Hollebeek, Srivastava, \& Chen, $\underline{2019)}$.

A high degree of participation can be a competitive objective for a broader spectrum of businesses in different industries. Engaged employees are devoted to their bosses, pleased with their jobs, and eager to devote more effort to meet the company's objectives. Literature indicates that engagement impacts many key human resources priorities, such as retention, work efficiency, absence, and (indirectly via the credibility of the employer) performance (Mach et al., 2020). Moreover, engaged employees can be some of companies biggest brand/service advocates in service encounters $\underline{(\mathrm{P} \text {. Li, Sun, Taris, }}$ Xing, \& Peeters, 2021). Engaged employee increases company's revenue and leads to customers' commitment (Mittal, Han,

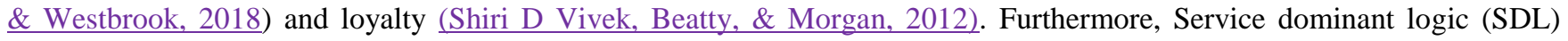
suggests that the consumer is considered as an active agent that interacts with service employees and helps in value cocreation (Akaka \& Vargo, 2015; Wajid, Raziq, Malik, Malik, \& Khurshid, 2019). 
Based on the S-D logic literature, actors within an ecosystem interact and integrate resources within a service system at the dyadic, servicescape, and eco-system level (Akaka \& Vargo, 2015; Frow, McColl-Kennedy, \& Payne, 2014). Customers for that matter engage on a dyadic level with the service front-line employees to integrate resources to co-create the service (Plé, 2016). The customer interacts through co-creation behaviors within these dyads (Yi \& Gong, 2013) in larger eco-systems (Jaakkola \& Alexander, 2014). Furthermore, these interactions within particular employee-customer dyads can lead towards interactions across the wider eco-system (R. J. Brodie, Fehrer, Jaakkola, \& Conduit, 2018; L. P. Li, Juric, \& Brodie, 2017). Similarly, Kumar and Pansari (2016) expressed engagement in both customer and employee context as "Engagement represents co-creation, interaction, solution development, and so on, all of which depend on the attitude that drives the behavior of customers and employees toward a firm (p. 498)". Moreover, CE is also defined as "a psychological state that occurs by interactive customer experiences with a focal object (e.g., a brand) in service relationships" (Brodie, Hollebeek, Jurić, \& Ilić, 2011, p. 260). Engaged customers' are tend to be more satisfied and loyal (Jaakkola \& Alexander, 2014).

The service sector in general and particularly insurance services require a significant level of interactions between service employee and customer, henceforth, both EE and CE are crucial for successful service encounters (Hollebeek et al., 2019; Kumar \& Pansari, 2016). CE is getting considerable attention in the last few years due to the dynamic and challenging environment particularly for the service sector (Pansari \& Kumar, 2018). Moreover, the theory of Service Profit Chain (SPC) expressed that employee engagement is an important antecedent for customer satisfying experience (Cain et al., 2018). Based on SPC, we believe that EE has an impact on the relationship attributes such as trust and commitment that will lead to customer engagement. Furthermore, the theory of $\mathrm{CE}$ suggests that $\mathrm{CE}$ occurs after the development of trust and commitment (Kumar, 2013).

Consequently, relationship marketing theories suggest that customers' trust, commitment, and loyalty are amongst the most important elements for sustainable competitive advantage (Pansari \& Kumar, 2018). Loyal customers are delighted customers that are having an optimistic view concerning a particular company (Mimouni Chaabane \& Pez, 2020). They possess re-patronage behavior and provide referrals. Loyal customers are very important for every organization, particularly service-oriented organizations including insurance services (Astuti \& Nagase, 2014).

Despite the importance of employee engagement, customers' engagement, and loyalty for the service sector, empirical literature concerning the mentioned variables is scarce (Brodie et al., 2011; Frow et al., 2014; Giovanis \& Athanasopoulou, 2018; Hollebeek et al., 2019; Jaakkola \& Alexander, 2014; L. P. Li et al., 2017; Lowe, 2012). CE has been extensively discussed by numerous researchers in different aspects such as; attitude, behavior, and metrics for measuring CE. For instance, CE has been investigated from the viewpoint of relationship marketing (J. L.-H. Bowden, 2009), S-D Logic (Brodie et al., 2011), customer contribution towards the firm (Kumar \& Pansari, 2016), and customer attitude towards the brand (Shiri D Vivek et al., 2012). However, efforts related to link EE with CE and loyalty directly and indirectly in general and particularly in insurance services are equal to naught. Hence, the primary aim of this study is to examine the indirect impact of employee engagement on customer loyalty through customer engagement.

This study is conducted in a utilitarian service setting such as insurance services. The reasons for conducting the current research in insurance services setup is that 1) the attachment level of the customer with service employee in this sector is considered as weak, 2) a lack of affective component in service provider and customer relationship (Bowden, Gabbott, \& Naumann, 2015), 3) it requires a significant level of interactions between the service provider and customer during service encounter to complete a transaction and 4) Despite the importance of EE and CE in insurance services, this sector got less attention by academician and researchers.

\section{LITERATURE REVIEW AND HYPOTHESES DEVELOPMENT}

\section{Employee Engagement (EE)}

EE is initially defined by Kahn (1990) as " the harnessing of organization members' selves to their work roles; in engagement, people employ and express themselves physically, cognitively, and emotionally during role performances (p. 694)". This definition is believed to be very comprehensive for it includes the physical, emotional, and cognitive attributes of EE. EE links to individual and organizational level outcomes. It is believed that engage employee embodies job satisfaction, participation, and interest in work (Cain et al., 2018). It has a strong relationship with customer satisfaction, customer loyalty, and overall firm performance (Harter, Schmidt, \& Hayes, 2002; Ram, Swapna, \& Prabhakar, 2011). The service sector, such as Insurance firms need front line employees who are physically, emotionally and cognitively engage in service encounter for a successful service outcome. Engage employees are better to equip for challenging service encounters (Slåtten \& Mehmetoglu, 2011), they work harder than dis-engaged employees (Cain et al., 2018) and they will go the extra mile to for customers' requirement (Macey \& Schneider, 2008). Thus, for frontline employees' readiness to go beyond their formal role for customer requirements, engagement can be considered as an essential attribute. 


\section{Employee engagement vs Customer loyalty}

Customers who return to the same service provider is considered as a loyal customer (Meesala \& Paul, 2018). In such a dynamic and challenging environment where consumerism is at the peak, service firms are highly dependent on loyal customers. Since in service sector such as insurance services require many interactions between service employee and customer, employee engagement is crucial for making customers loyal (Brodie et al., 2011). Furthermore, service-profit chain (SPC) theory suggests that employee engagement in a service encounter leads to customers' satisfaction which further leads to loyalty (Frennea, Mittal, \& Westbrook, 2014). Hence, it can be assumed from the above literature that more engaged employee will enhance customer loyalty thus the first hypothesis of the study is;

H1: Employees engagement significantly enhances customers' loyalty.

\section{Employee Engagement vs Customer Engagement}

Brodie et al. (2011) proposed that "customer engagement reflect a psychological state, which occurs by interactive customer experiences with a focal object (e.g., a brand) in-service relationship" (p. 260). Similarly, SDL suggests that the consumer is considered as an active member that engages in interaction with service employees and helps value co-creation practice (Frow et al., 2014; Hollebeek et al., 2019; Wajid et al., 2019). CE alone may not be enough in service encounters, service employee and customer should work together for the successful service encounter (Coulter, 2011). Notwithstanding, Kumar and Pansari (2016) defined engagement in both customer and employee context as "Engagement represents co-creation, interaction, solution development, and so on, all of which depend on the attitude that drives the behavior of customers and employees toward a firm. We define engagement as the attitude, behavior, the level of connectedness (1) among customers, (2) between customers and employees, and (3) of customers and employees within a firm" (p. 498). Hence, it can be argued from the above literature that employee engagement in an interaction between service employee and customer in a service encounter may lead to customer engagement. Thus the $2^{\text {nd }}$ hypothesis of the study is developed.

H2: Employee engagement has a significant positive impact on customers' engagement.

\section{Moderating Role of Trust}

Environmental factors such as technology, competition, and the growing trend of consumerism have forced companies to focus on customer relationships. Customers are considered the primary contributor to firms' performance when they feel connected to the firm (Kumar, 2013). Pansari and Kumar (2017), argued that the level of happiness and emotional interaction depends on the relationship between the company and the customer. Moreover, they argued that attributes of relationship marketing such as; satisfaction, trust, and commitment are the important elements for CE. Similarly, the theory of CE argued that customer engagement occurs only after trust and commitment are achieved (Kumar, 2013). Henceforth, the attributes of relationship marketing are incorporated in engagement theory, therefore it can be argued that logically CE comes after the relationship is formed. Furthermore, the role of trust as a moderator has already been verified in various context by many scholars (see e.g, Emmanuel, 2020; Hamakhan, 2020). Thus, it can be inferred from the above literature, that the link of EE and $\mathrm{CE}$ will positively be strengthened due to the interaction of trust.

H3: Customers' trust positively moderates the link of EE-CE.

\section{Mediating Role of CE}

Kumar and Pansari (2016) confirm the effect of EE on CE in both; manufacturing and service firms. Similarly, Wangenheim, Evanschitzky, and Wunderlich (2007) empirically confirm the positive effect EE on CE. Moreover, SDL endorsed the role of EE and CE in a service encounter for value co-creation (Frow et al., 2014; Hollebeek et al., 2019; Wajid et al., 2019). Consequently, those customers who are highly engaged with service employees tend to be more satisfied and loyal (Cain et al., 2018). Numerous scholars had worked on customer-brand relationship concepts such as; customer satisfaction, trust, service quality in relationship with CE (Brodie et al., 2011; Hollebeek, 2011; So, King, \& Sparks, 2014; Shiri D Vivek et al., 2012). Moreover, SPC claims that employee who is motivated and highly engaged in service encounter leads to customer loyalty (Kim, 2014). Furthermore, J. L.-H. Bowden (2009) argued that CE is a mental process that helps in creating and sustaining loyalty for new and existing customers respectively. In addition (Yen, Teng, \& Tzeng, 2020) also confirms the role of customers' engagement as a mediator between innovativeness and customer value co-creation. Hence, from the above discussion, it can be assumed that employee engagement attitude will encourage customers' participation in service encounters which will further lead to patient loyalty.

H4: CE significantly mediates the link between EE-CL. 


\section{Conceptual Framework}

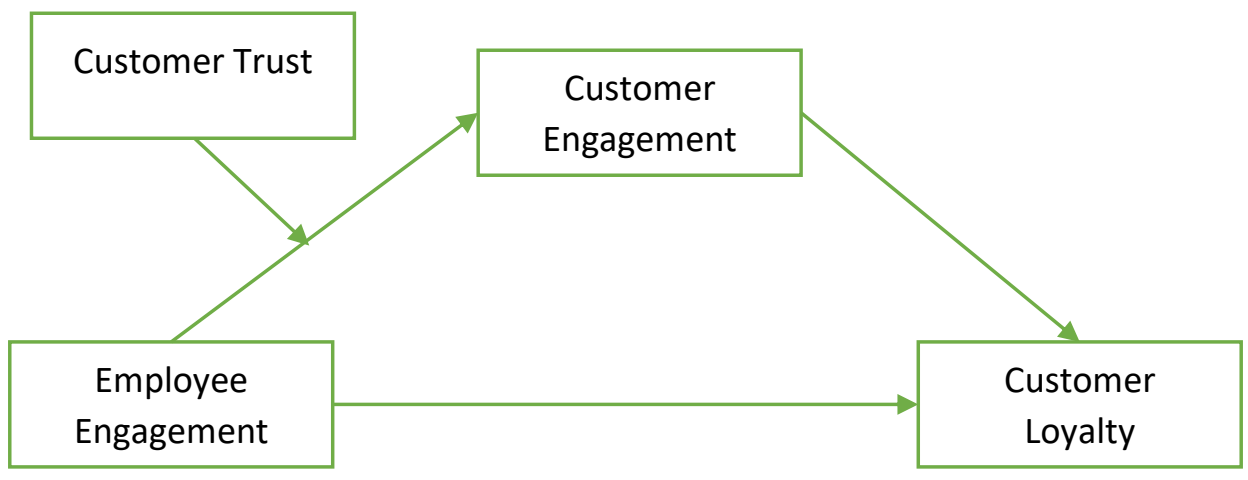

Figure 1: Conceptual Framework

\section{METHODOLOGY}

\section{Participants and Procedure}

This study intends to investigate the mechanism through which EE affects CL. The study is based on a descriptive approach and data were collected through an adopted questionnaire from the customers of the insurance company. Since it's not sensible to introduce each subject into the analysis, convenience sampling is used for knowledge assortment in line with varied conditions together with accessibility and availableness of the respondents (Dörnyei, 2007). A total of 336 questionnaires were distributed. Out of 336, we got 250 questionnaires from respondents by removing some incomplete questionnaires we used 220 questionnaires for the analysis purpose.

\section{Measurement Scale}

Employees' Engagement: EE is measured through the scale developed by Schaufeli et al. (2002). It consists of 6 items including ("At my work, I feel bursting with energy"; “At my job, I feel strong and vigorous"). The Cronbach's alpha for EE was 0.81 .

Customer Engagement: For the customer engagement scale, we used the scale developed by Shiri Dalela Vivek (2009) with minor modifications to make it fit for the insurance context. CE scale consists of 40 items including ("I am very obsessed with XYZ insurance company"; "I feel very engaged while interacting with XYZ company"). The Cronbach's alpha for the CE scale was 0.83 .

Customers' Trust: Customers' trust scale was adopted from Malhotra, Kim, and Agarwal (2004). It comprises 5 items including ("the employee of the insurance company is trustworthy in handling my personal information"; "I trust that this loyalty program would keep my best interests in mind when dealing with my personal information"). The Cronbach's alpha for customers' trust was found 0.86 .

Customers' Loyalty: CL was measured with the help of a scale developed by Zeithaml, Berry, and Parasuraman (1996). It consists of 5-items including ("I am likely to say positive things about [the store] to other people"; "I would recommend $\mathrm{XYZ}$ to someone who seeks my advice"). The Cronbach's alpha value for the CL scale was found as 0.84 .

\section{RESULTS}

Table no. 1 presents the descriptive analysis of the variables along with the correlations analysis.

Table 1: Descriptive Statistics

\begin{tabular}{lllllll}
\hline & Mean & SD & 1 & 2 & $\mathbf{3}$ & $\mathbf{4}$ \\
\hline EE & 5.992 & 1.643 & $(0.77)$ & & & \\
\hline TRUST & 28.484 & 5.768 & $0.569^{* *}$ & $(0.839)$ & & \\
\hline CE & 28.978 & 5.253 & $0.421^{* *}$ & $0.600^{* *}$ & $(0.77)$ & \\
\hline CL & 9.937 & 2.377 & $0.344^{* *}$ & $0.375^{* *}$ & $0.550^{* *}$ & $(0.77)$ \\
\hline $\mathrm{P}<0.001$ & & & & & & \\
\hline
\end{tabular}

\section{Model Fit Indices}

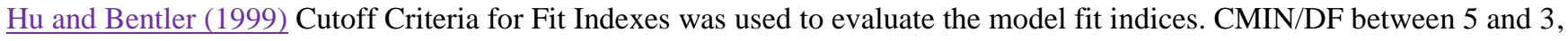


CFI less than 0.95, SRMR less than 0.06, RMSEA less than 0.08, and PClose greater than 0.05 are the acceptable thresholds for model fitness. Therefore, the model is found fit for further analysis.

Based on the fit indices and the threshold criteria set by $\mathrm{Hu}$ and Bentler (1999), all the individual models and the measurement model are a reasonable fit for further analysis (see table 2)

Table 2: Model Fit Indices

\begin{tabular}{llllllll}
\hline & CMIN & DF & CMIN/DF & CFI & SRMR & RMSEA & PClose \\
\hline 1 Factor Model & 1090.991 & 119 & 9.168 & 0.666 & 0.099 & 0.129 & $<0.001$ \\
\hline 2 Factor Model & 804.506 & 118 & 6.818 & 0.764 & 0.082 & 0.109 & $<0.001$ \\
\hline 3 Factor Model & 615.736 & 116 & 5.308 & 0.828 & 0.072 & 0.094 & $<0.001$ \\
\hline 4 Factor Model & 432.998 & 112 & 3.866 & 0.9 & 0.055 & 0.076 & $<0.001$ \\
\hline Model 1 & $1^{\text {st }}$ factor (EE, TRUST, CE, Customer loyalty) & & \\
\hline Model 2 & $1^{\text {st }}$ factor (EE, TRUST), ${ }^{\text {nd }}$ Factor (CE, LOYL) & & \\
\hline Model 3 & $1^{\text {st }}$ factor (TRUST), $2^{\text {nd }}$ Factor (CE, LOYL), $3^{\text {rd }}$ factor (EE) & \\
\hline Model 4 & $1^{\text {st }}$ factor (TRUST), $2^{\text {nd }}$ Factor (CE), $3^{\text {rd }}$ factor $(E E), 4^{\text {th }}$ factor (CL) \\
\hline
\end{tabular}

Table 3 shows significant effects of independent variable $E E$ on the mediator $C E(\beta=1.345, p<0.01)$. Furthermore, the effects of independent variable $\operatorname{EE}(\beta=0.215, \mathrm{p}<0.01)$, mediator $\mathrm{CE}(\beta=0.342, \mathrm{p}<0.01)$, moderator trust $(\beta=0.125, \mathrm{p}<0.05)$ and the interaction term between $\mathrm{EE}$ and trust $(\beta=0.130, \mathrm{p}<0.05)$ on the dependent variable customer loyalty are also significant. Based on the results of table 3 the direct effects of the EE on CL were calculated which are also significant $(\beta=0.215$, $\mathrm{p}<0.01, \mathrm{LLCI}=0.084$ and ULCI=0.346). Conditional indirect effects of EE on CL through CE and moderated by the trust are also significant $(\beta=0.288, \mathrm{p}<0.01, \mathrm{LLCI}=0.214$ and $\mathrm{ULCI}=0.375)$. These effects were plotted in figure 2 which is as follows.

Table 3: Regression Analysis

\begin{tabular}{lll}
\hline & Model 1 & Model2 \\
\hline Independent Variable & CE & CL \\
\hline EE & $1.345^{* *}$ & $0.215^{* *}$ \\
\hline CE & & $0.342^{* *}$ \\
\hline TRUST & $0.125^{*}$ \\
\hline EE x TRUST & & $0.130^{*}$ \\
\hline $\mathrm{r}^{2}$ & $0.177^{* *}$ & $0.324^{* *}$ \\
\hline $\mathrm{F}$ & 105.483 & 58.3589 \\
\hline$* \mathrm{p}<0.05, * * \mathrm{p}<0.01$ & & \\
\hline
\end{tabular}

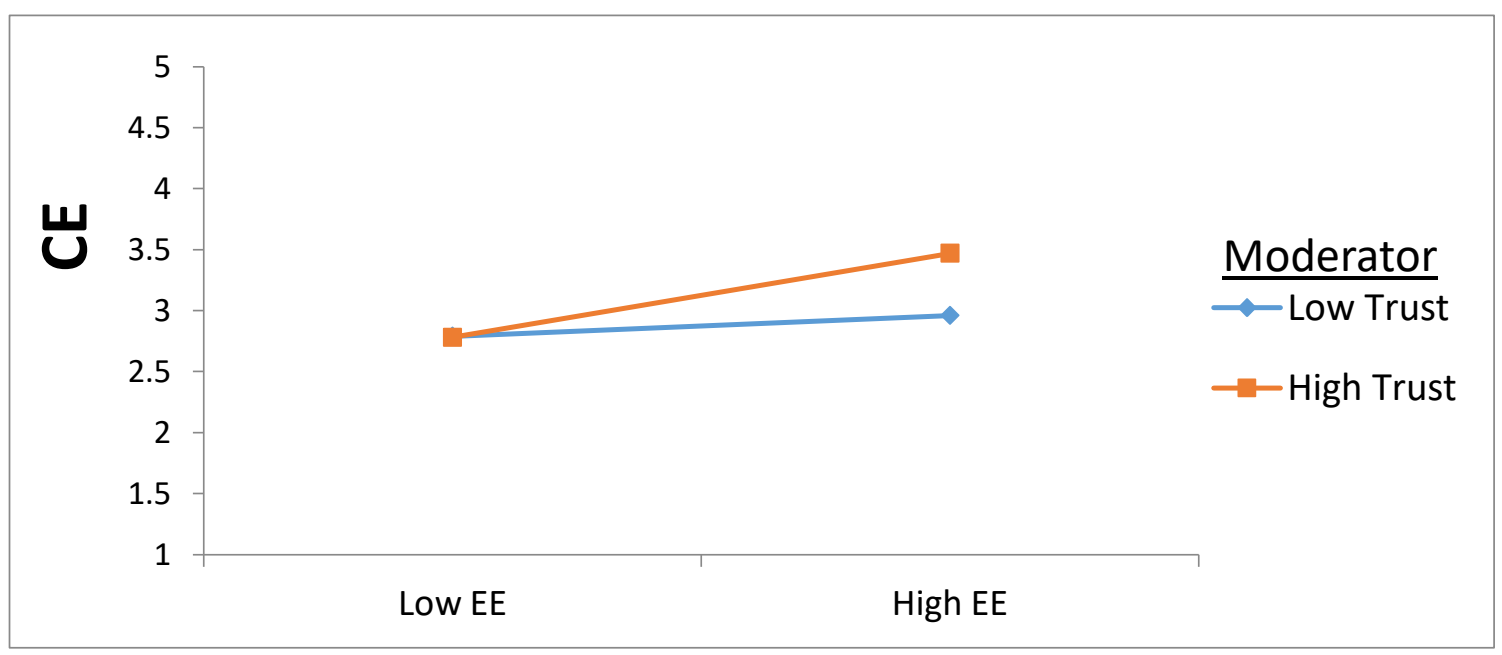

Figure 2: Conditional effects vs employee engagement

\section{DISCUSSION}

The literature has acknowledged $\mathrm{EE}$ and $\mathrm{CE}$ as strategic importance for building relationships between customers and employees. The current study was intended to examine the impact of EE on CL. Moreover, it investigated the mechanism through which EE affects CL. Empirical data were collected through an adapted questionnaire from 220 customers of 
various insurance companies. After analysis, it was found that EE directly affects CL. As suggested by SPC theory, an engaged employee would lead to customers' satisfaction and repeat purchase behavior (Brodie et al., 2011; Frennea et al., 2014) supports the finding of the first hypothesis. The finding was also consistent with previous findings of (Afridi, Shahjehan, Haider, \& Munawar, 2020). Moreover, the mediating effect of CE between the association of EE and CL was examined. It was found that both the direct and indirect effect of EE on CL was significant. It shows that CE partially mediates the underlying association. The findings of this hypothesis are consistent with previous studies such as (Cain et al., 2018; Yen et al., 2020). Afterward, the moderating effect of customer trust was examined between the link of EE and CE. It was found that adding trust as an interacting term with EE, strengthens the positive effect of EE on CE. The results are consistent with CE theory that advocates that customers would engage more interactively and emotionally with the company they trust more (Kumar, 2013). Finally, the moderating, mediating effect of trust-based customers' engagement was examined. Results suggest that trust-based customer engagement fully mediates the association. The findings of this hypothesis are consistent with S-D logic, value co-creation literature, and CE theories that suggest that dyadic engagement between the customer and employee in service encounters leads towards outcomes like customer loyalty (Frow et al., 2014; Hamakhan, 2020; Kumar, 2013).

\section{CONCLUSION}

This study was intended to examine the role of EE, CE, and CT in enhancing CL. For this purpose, the data were collected from 220 insurance customers through the non-probability sampling technique. Empirical data were tested with the help of Andrew hayes model 7. Findings revealed that employee engagement has a significant positive impact on customers; loyalty. Moreover, data confirm that customers' engagement partially mediates the association of EE-CL. Results revealed that Customers' trust significantly and positively moderates the link of EE-CE. And trust-based customers' engagement significantly mediates the link between EE-CL.

\section{CONTRIBUTION IN THE STUDY AREA}

The present study contributed theoretically by adding literature regarding EE, CE, CT, and CL in general and particularly in utilitarian services such as insurance services. The role of the employee in general and particular for the service sector such as insurance company is very crucial, for it has a direct interaction of employee and customer. Previous studies were related to the direct effect of EE on customer satisfaction (Brodie et al., 2011; Frennea et al., 2014), however, the present study extended their study and verify the impact of EE on CL. Moreover, this study added literature in terms of EE by examining its importance in making customers loyal. Also, this study verified the mechanism behind the link between EE and CL. Finally, the findings of the present study unfold a new term (trust-based customer engagement) as the underlying mechanism between $\mathrm{EE}$ and $\mathrm{CL}$.

\section{LIMITATION AND FUTURE RESEARCH RECOMMENDATION}

Just like other studies, this research has also some limitations. First of all the data were gathered purely from those who were using insurance services. It may lead to the generalizability and validity issue. Second, that data were cross-sectional while the experimental design is recommended for future research. Third, only one mediator and one moderator were used to examining the underlying mechanism, however, more potential mediators and moderators could be explored between the link of EE and CL. This study uses CE as a mediator while CT as moderator, however, other potential variables such as; employees' volunteerism, employees' self-efficacy, and employees' reliability.

\section{ACKNOWLEDGEMENT}

We would like to thank all the independent reviewers of HSSR who conducted a feasibility study of our research work.

\section{AUTHORS CONTRIBUTION}

All authors of this research paper have directly participated in the planning and execution of this study. Dr. Sajjad Ahmad Afridi and Dr. Wajid Khan wrote the research paper and design the organization of this paper. Dr. Asad Javed, Muhammad Waseem, and Kaleem Saifullah did the methodological part of this paper including; statistical analysis, interpretations, and technical parts.

\section{REFERENCES}

1. Afridi, S. A., Shahjehan, A., Haider, M., \& Munawar, U. (2020). Test of Mediation and Moderation between Employee Empathy and Customers' Advocacy. Abasyn University Journal of Social Sciences, 13(2). https://doi.org/10.34091/AJSS.13.1.09

2. Akaka, M. A., \& Vargo, S. L. (2015). Extending the context of service: from encounters to ecosystems. Journal of Services Marketing, 29(6/7), 453-462. https://doi.org/10.1108/JSM-03-2015-0126 
3. Astuti, H. J., \& Nagase, K. (2014). Patient loyalty to healthcare organizations: Relationship marketing and satisfaction. International Journal of Management and Marketing Research, 7(2), 39-56.

4. Bowden, Gabbott, M., \& Naumann, K. (2015). Service relationships and the customer disengagementengagement conundrum. Journal of marketing management, 31(7-8), 774-806. https://doi.org/10.1 080/0267257X.2014.983143

5. Bowden, J. L.-H. (2009). The process of customer engagement: a conceptual framework. Journal of marketing theory and practice, 17(1), 63-74. https://doi.org/10.2753/MTP1069-6679170105

6. Brodie, Hollebeek, L. D., Jurić, B., \& Ilić, A. (2011). Customer engagement: Conceptual domain, fundamental propositions, and implications for research. Journal of service research, 14(3), 252-271. https://doi.org/10.1177/1094670511411703

7. Brodie, R. J., Fehrer, J. A., Jaakkola, E., \& Conduit, J. (2018). Actor Engagement in Networks: Defining the Conceptual Domain. Journal of service research, 1094670519827385.

8. Cain, L., Tanford, S., \& Shulga, L. (2018). Customers' Perceptions of Employee Engagement: Fortifying the Service-Profit Chain. International Journal of Hospitality \& Tourism Administration, 19(1), 52-77. https://doi.org/10.1080/15256480.2017.1305312

9. Coulter, A. (2011). Engaging patients in healthcare: McGraw-Hill Education (UK).

10. Dörnyei, Z. (2007). Research methods in applied linguistics: Quantitative, qualitative, and mixed methodologies: Oxford University Press Oxford.

11. Emmanuel, M. (2020). Impact of Inclusive Leadership on Innovative Work Behavior with Mediating Role of Employee Volunteer and Moderating Role of Trust in Leadership. CAPITAL UNIVERSITY.

12. Frennea, C., Mittal, V., \& Westbrook, R. A. (2014). 10 the satisfaction profit chain. Handbook of service marketing research, 182. https://doi.org/10.4337/9780857938855.00017

13. Frow, P., McColl-Kennedy, J. R., \& Payne, A. (2014). Co-creation practices: Their role in shaping a health care ecosystem. Industrial Marketing Management, 56, 24-39. https://doi.org/10.1016/j.indmarman.2016.03.007

14. Giovanis, A. N., \& Athanasopoulou, P. (2018). Consumer-brand relationships and brand loyalty in technologymediated services. Journal of Retailing and Consumer Services, 40, 287-294. https://doi.org/10.1016 j.j.jretconser.2017.03.003

15. Hamakhan, Y. T. M. (2020). The effect of individual factors on user behaviour and the moderating role of trust: an empirical investigation of consumers' acceptance of electronic banking in the Kurdistan Region of Iraq. Financial Innovation, 6(1), 1-29. https://doi.org/10.1186/s40854-020-00206-0

16. Harter, J. K., Schmidt, F. L., \& Hayes, T. L. (2002). Business-unit-level relationship between employee satisfaction, employee engagement, and business outcomes: A meta-analysis. Journal of applied Psychology, 87(2), 268. https://doi.org/10.1037/0021-9010.87.2.268

17. Hollebeek, L. D. (2011). Demystifying customer brand engagement: Exploring the loyalty nexus. Journal of marketing management, 27(7-8), 785-807. https://doi.org/10.1080/0267257X.2010.500132

18. Hollebeek, L. D., Srivastava, R. K., \& Chen, T. (2019). SD logic-informed customer engagement: integrative framework, revised fundamental propositions, and application to CRM. Journal of the academy of Marketing Science, 47(1), 161-185. https://doi.org/10.1007/s11747-016-0494-5

19. Hu, L. t., \& Bentler, P. M. (1999). Cutoff criteria for fit indexes in covariance structure analysis: Conventional criteria versus new alternatives. Structural equation modeling: a multidisciplinary journal, 6(1), 1-55. https://doi.org/10.1080/10705519909540118

20. Jaakkola, E., \& Alexander, M. (2014). The role of customer engagement behavior in value co-creation: a service system perspective. Journal of service research, 17(3), 247-261. https://doi.org/10.1177/1094670514529187

21. Kahn, W. A. (1990). Psychological conditions of personal engagement and disengagement at work. Academy of Management journal, 33(4), 692-724. https://doi.org/10.5465/256287

22. Kim, N. (2014). Employee turnover intention among newcomers in travel industry. International Journal of Tourism Research, 16(1), 56-64. https://doi.org/10.1002/jtr.1898

23. Kumar, V. (2013). Profitable customer engagement: Concept, metrics and strategies: SAGE Publications India.

24. Kumar, V., \& Pansari, A. (2016). Competitive advantage through engagement. Journal of Marketing Research, 53(4), 497-514. https://doi.org/10.1509/jmr.15.0044

25. Li, L. P., Juric, B., \& Brodie, R. J. (2017). Dynamic multi-actor engagement in networks: the case of united breaks guitars. Journal of Service Theory and Practice, 27(4), 738-760. https://doi.org/10.1108/JSTP-04-2016-0066

26. Li, P., Sun, J.-M., Taris, T. W., Xing, L., \& Peeters, M. C. (2021). Country differences in the relationship between leadership and employee engagement: A meta-analysis. The Leadership Quarterly, 32(1), 101458. https://doi.org/10.1016/j.leaqua.2020.101458

27. Lowe, G. (2012). How employee engagement matters for hospital performance. Healthcare Quarterly, 15(2), 2939. https://doi.org/10.12927/hcq.2012.22915 
28. Macey, W. H., \& Schneider, B. (2008). The meaning of employee engagement. Industrial and Organizational Psychology, 1(1), 3-30. https://doi.org/10.1111/j.1754-9434.2007.0002.x

29. Mach, K. J., Lemos, M. C., Meadow, A. M., Wyborn, C., Klenk, N., Arnott, J. C., . . . Nichols, L. (2020). Actionable knowledge and the art of engagement. Current Opinion in Environmental Sustainability, 42, 30-37. https://doi.org/10.1016/j.cosust.2020.01.002

30. Malhotra, N. K., Kim, S. S., \& Agarwal, J. (2004). Internet users' information privacy concerns (IUIPC): The construct, the scale, and a causal model. Information systems research, 15(4), 336-355. https://doi.org/10.1287/isre.1040.0032

31. Meesala, A., \& Paul, J. (2018). Service quality, consumer satisfaction and loyalty in hospitals: Thinking for the future. Journal of Retailing and Consumer Services, 40, 261-269. https://doi.org/10.1016/j.jretconser.2016.10.011

32. Mimouni Chaabane, A., \& Pez, V. (2020). The reward gap in hierarchical loyalty programmes: how to enhance bottom-tier customers' loyalty without alienating top-tier customers. Journal of Marketing Management, 36(1-2), 51-71. https://doi.org/10.1080/0267257X.2019.1694565

33. Mittal, V., Han, K., \& Westbrook, R. A. (2018). Customer Engagement and Employee Engagement: A Research Review and Agenda Customer Engagement Marketing (pp. 173-201): Springer. https://doi.org/10.1007/978-3$\underline{319-61985-9 \quad 8}$

34. Pansari, A., \& Kumar, V. (2017). Customer engagement: the construct, antecedents, and consequences. Journal of the Academy of Marketing Science, 45(3), 294-311. https://doi.org/10.1007/s11747-016-0485-6

35. Pansari, A., \& Kumar, V. (2018). Customer engagement marketing (pp. 1-27): Springer. https://doi.org/10.1007/978-3-319-61985-9_1

36. Plé, L. (2016). Studying customers' resource integration by service employees in interactional value co-creation. Journal of Services Marketing, 30(2), 152-164. https://doi.org/10.1108/JSM-02-2015-0065

37. Ram, P., Swapna, B. G., \& Prabhakar, G. V. (2011). Work environment, service climate, and customer satisfaction: Examining theoretical and empirical connections. International Journal of Business and Social Science, 2(20).

38. Schaufeli, W. B., Salanova, M., González-Romá, V., \& Bakker, A. B. (2002). The measurement of engagement and burnout: A two sample confirmatory factor analytic approach. Journal of Happiness studies, 3(1), 71-92. https://doi.org/10.1023/A:1015630930326

39. Slåtten, T., \& Mehmetoglu, M. (2011). Antecedents and effects of engaged frontline employees: A study from the hospitality industry. Managing Service Quality: An International Journal, 21(1), 88-107. https://doi.org/10.1108/09604521111100261

40. So, K. K. F., King, C., \& Sparks, B. (2014). Customer engagement with tourism brands: Scale development and validation. Journal of Hospitality \& Tourism Research, 38(3), 304-329. https://doi.org/10.1177/1096348012451456

41. Vivek, S. D. (2009). A scale of consumer engagement. University of Alabama Libraries.

42. Vivek, S. D., Beatty, S. E., \& Morgan, R. M. (2012). Customer engagement: Exploring customer relationships beyond purchase. Journal of marketing theory and practice, 20(2), 122-146. https://doi.org/10.2753/MTP10696679200201

43. Wajid, A., Raziq, M. M., Malik, O. F., Malik, S. A., \& Khurshid, N. (2019). Value co-creation through actor embeddedness and actor engagement. Marketing Intelligence \& Planning. https://doi.org/10.1108/MIP-07-2018$\underline{0241}$

44. Wangenheim, F. v., Evanschitzky, H., \& Wunderlich, M. (2007). Does the employee-customer satisfaction link hold for all employee groups? Journal of Business Research, 60(7), 690-697. https://doi.org/10.1016 /j.jbusres.2007.02.019

45. Yen, C.-H., Teng, H.-Y., \& Tzeng, J.-C. (2020). Innovativeness and customer value co-creation behaviors: Mediating role of customer engagement. International journal of hospitality management, 88, 102514. https://doi.org/10.1016/j.ijhm.2020.102514

46. Yi, Y., \& Gong, T. (2013). Customer value co-creation behavior: Scale development and validation. Journal of Business Research, 66(9), 1279-1284. https://doi.org/10.1016/j.jbusres.2012.02.026

47. Young, H. R., Glerum, D. R., Wang, W., \& Joseph, D. L. (2018). Who are the most engaged at work? A meta-analysis of personality and employee engagement. Journal of Organizational Behavior, 39(10), 1330-1346. https://doi.org/10.1002/job.2303

48. Zeithaml, V. A., Berry, L. L., \& Parasuraman, A. (1996). The behavioral consequences of service quality. Journal of marketing, 60(2), 31-46. https://doi.org/10.1177/002224299606000203 